\title{
Academic Procrastination on Digital Native Higher Degree Student: Does it Really Matter?
}

\author{
${ }^{1 \text { st }}$ Salsabiila Sholehah \\ Department of Accounting \\ Education, Faculty of Teacher \\ Training and Education \\ Universitas Sebelas Maret \\ Surakarta, Indonesia, 57126 \\ sholehah.salsabiila@gmail.com
}

\author{
2nd Khresna Bayu Sangka \\ Department of Accounting \\ Education, Faculty of Teacher \\ Training and Education \\ Universitas Sebelas Maret \\ Surakarta, Indonesia, 57126 \\ b.sangka@staff.uns.ac.id
}

\author{
3rd Nurhasan Hamidi \\ Department of Accounting \\ Education, Faculty of Teacher \\ Training and Education \\ Universitas Sebelas Maret \\ Surakarta, Indonesia, 57126 \\ nurhasan_hamidi@yahoo.com
}

\begin{abstract}
According to a survey conducted at 2017 by Association of Internet Network Providers Indonesia (APJII), the number of internet users in Indonesia has reached 143.26 million people or equivalent to $54.68 \%$ of the total population, the major internet users was contributed by people aged 19-34 known as Generation $Z$, a generation who was born and live with the rapid growth of internet and digital era. Internet has become a source of information that is very important to support student academic's life, to some extent it has been impacted to change their behavior in various academic aspects. Motivation of this study was to investigate the correlation of academic procrastination and information/digital literacy while conducting their higher degree education in Faculty of Teaching Learning and Education, Universitas Sebelas Maret. This study explored how'd the students' characteristic and the importance of information/digital literacy have influenced students' daily activities. Employed extensive literature reviews, this preliminary study found a positive correlation between academic procrastination positively or negatively impacted by the internet existence for this generation. These findings are very critical for any higher educations' providers and lecturers to be used as a basic consideration to re-design the academic tasks and projects in learning process.
\end{abstract}

Keywords - academic procrastinaion, generation Z, higher degree student

\section{INTRODUCTION}

Along with the development of technology and information, now the internet has become a main source of information that very common for student life. According to a survey conducted at 2017 by Association of Internet Network Providers Indonesia (APJII), the results shown that Internet users in Indonesia has reached 143.26 million people or equivalent to $54.68 \%$ of the total population. If this result broken down by age, $49.52 \%$ of them were contributed by people aged 19-34 years which many of them are still conducting their study. This age range known as Generation Z or Digital Native.

Based on Seemiller and Grace's (2016) research reported that Generation $\mathrm{Z}$ or Digital Natives comprise the dominant generation of students currently entering college. The entry of generation $\mathrm{Z}$ to college, a new challenge for educators because of its characteristics are different from previous generations. Bencsik \& Machova (2016) one of the main factors that distinguish between the characteristics of generation $\mathrm{z}$ with another generation is the mastery of information and technology.

The development of information and communication technology today makes it easier for someone to gain access to information. The ability to access, evaluate and use information from varied sources known as information literacy (Doyle in Baskoro and Jonatan, 2015). Information litercacy is a very important ability to have someone, especially in the academic world, especially for the Digital Native High Student. Digital Native's skill is largely overlapped with information literacy skills and competencies (Sorgo, Bartol, Dolnicar, \& Podgomik, 2016: 2).

The development of technology and information can cause positive and negative impacts for Digital Native student life. One of them is academic procrastination. According to the Head in Dubnjakovic (2018: 3) Indeed, the study show research is the top reported reason for poor performance on written assignments in social studies and humanities, followed by information overload, with most students characterizing the task as "barely tolerable". With the information literacy, digital natives student (with its characteristics) is expected to be able to access, evaluate and use the information needed effectively. 
Drawing from the background above, motivation of this study was to investigate the relationship of Academic Procrastination and Digital Native High Student. This study undertaken in the setting of Faculty of Teacher Training and Education.

\section{METHOD}

The research method used in this research is Extensive Literature Reviews. This study explored how'd the students' characteristic and the importance of information/digital literacy have influenced students' daily activities.

\section{RESULTS AND DISCUSSION}

\section{A. Z Generation in Higher Education}

Bencsik, Csikos, and Juhes (2016) studies show the entry of $\mathrm{Z}$ generation in the generation group, which can be seen in the following table:

TABLE 1. GENERATION DIFFERENCES

\begin{tabular}{cc}
\hline Born Year & Name \\
\hline $1925-1946$ & Veteran generation \\
$1946-1960$ & Baby boom generation \\
$1960-1980$ & X generation \\
$1980-1995$ & Y generation \\
$1995-2010$ & Z generation \\
$2010+$ & Alfa generation \\
\hline
\end{tabular}

The youngest generation currently studying in college is the $\mathrm{z}$-generation, also called iGeneration or internet generation. According to the results of Bencsik \& Machova (2016) one of the main factors that distinguish the characteristics between the $\mathrm{z}$ generation with another generation is the mastery of information and technology. For the $\mathrm{Z}$ generation information and technology are things that have become part of their lives, because they are born where access to information, especially the Internet has become a global culture, so that it affects their values, views and goals (Son 2016 132). While Dance (in Bencsik, Csikos, and Juhaz, 2016: 93) states that "Compared with generation $\mathrm{Y}$, the generation $\mathrm{Z}$ is not aware of concept of struggling. They are practical, rather intelegent than wise and they like to take the lead as they are brave. Ther are more impatient and more agile than their predecessors and they look for new challenges and impulses continuously. They are not afraid of continuous changes and due to the world of internet they possess much information, but just to a certain extent. To solve problem, they try to find the solutions on the internet". Generation Z are also (West, 2014): (1) well-integrated with technology; they are often referred to as "digital natives"; (2) social media savvy; (3) multitaskers; (4) concerned about the environment; (5) influenced by their friends about product and brands; (6) smart, with the ability to process a lot of information quickly.
Today several generations of $\mathrm{Z}$ have entered higher education. This is supported by research results titled $\mathrm{Z}$ Generation Goes to College. In this study, Seemiller and Grace (2016) report that the Digital Natives comprise the dominant generation of students currently entering college. In their study, Gen-Zers described themselves as loyal, thoughful, compassionate, open-minded, and responsible-a rather affable self-description. They also admit to feeling overwhelmed by the availability of information and need help in evaluating it. Kathleen and Eric (2017: 87-88)

"Digital Natives have grown up in Information Age and while comfortable with technology to access the plethora of news bits and sound bites, they might need guidance in how to sift, sort, and synthesize information with help in avoiding overload, checking accuracy, and evaluating information. Many youth have succumbed to bring watching of favorite shows and instructors may not understand or identify how current students can get caught up in, or lost on, the Internet. Assignments that require student to access information online should be very clear as to goals, sources, time-spent, ways to glean and evaluate the content".

\section{B. The Important of Information Literacy on Digital Natives High Student}

The development of information and communication technology today makes it easier for someone to gain access to information. For the $\mathrm{Z}$ generation information and technology are things that have become part of their lives, because they are born where access to information, especially the Internet has become a global culture, so that it affects their values, views and life goals (Putra, 2016: 132). According to Yudhisthira (2017: 98) the ability to obtain information in the fulfillment of information needs does not appear by itself, so the ability to obtain information is the ability possessed by everyone with different levels of ability. The ability to access, evaluate and use information from varied sources is known as information literacy (Doyle in Baskoro \& Jonatan, 2015).

Information literacy is a very important ability to have someone, especially in the academic world, especially for Digital Native High Student. Digital Native's skill largely overlap with information literacy skills and competencies (Sorgo, Bartol, Dolnicar, \& Podgornik, 2016: 2). According Association of College and Research Libraries (ACRL) about Information Literacy Competency Standards for Higher Education, an information literate student is able to: (1) determines the nature and extent of the information needed; (2) acccesses needed information effectively and efficiently; (3) evaluate information and its sources critically and incorporates selected information into his or her knowledge base and value system; (4) individually or as a member of a group, uses 
information effectively to accomplish a spesific purpose; (5) understands many of economic, legal, and social issues surrounding the use of information and accesses and use information ethically and legally.

\section{Student Learning and Information Literacy}

Information literacy empowers people to make knowledgeable decisions for a life time, including personal and political decisions, and equips them to address educational needs (Grassian, 2017: 232-233). According to Doyle in Yudhisthira (2017: 99) by possessing information literacy skills an individual is able to determine accurate and complete information that will be the basis for making decisions such as: (a) define the required information restrictions; (b) formulate information needs; (c) identify potential sources of information; (d) develop a successful search strategy. (e) access the information needed effectively and efficiently; (f) evaluate information; (g) organize information; (h) combining selected information becomes the foundation of one's knowledge; (i) use information effectively to achieve certain goals.

Ease of access and abundance of information obtained through the internet, on the other hand it causes students to be less selective in choosing the source of information that will be used (Nurjanah, Rusmana, and Yanto, 2017: 118). Everyone can create, access, use and share or share information and knowledge, with the consequence that everyone should be able to deal with and master the information correctly (Sukaesih and Rohman, 2013: 62). However, the ease of sharing and accessing digital information through the internet, it resulted in a lot of information that can not be accounted for widely circulated through various digital publications such as blogs or wordpress media that does not include the clarity of information sources, and it is still a lot of students who use the information as a reference task academic while on the internet is also available digital information sources such as electronic resources (e-resources) that is open access that can be accessed by using personal computers, mainframes, or mobile devices remotely via internet or intranet consisting of various types such as e-book, e-journal, full text database, database indexing and abstracting, e-images, eaudio, video, and others (Surachman, 2012: 2).

\section{Academic Procrastination on Digital Natives High Student}

Ferrari (Ghufron and Risnawita, 2012: 158) says that as a behavioral delay, academic procrastination can be manifested in certain indicators that can be measured and observed through the following four traits: (1) procrastination to start completing the task at hand; (2) delays in completing tasks; (3) the time gap between the established plan and the actual performance; and (4) doing other activities that are more fun than the task to be done.

Ferrari and Milgram (Scraw, et.al., 2007: 12) also stated that "These findings suggest that procrastination is an impediment to academic success because it decreases the quality and quantity of learning while increasing the severity of stress and negative outcomes in student's lives ".Furthermore, Ana Dubnjakovic (2018: 1-15) in her study found that procrastination was the top reported reason for poor performance on written assignments in social studies and humanities, followed by information overload, with most students characterizing the task as "barely tolerable".

Dubnjakovic (2018: 4) also states that "in addition to the involve internal (i.e., focused on individual) justifications of behavior. For instance, wishful thinking items reference student's ability, physical problems refer to general health, while inertia indicates lack of motivation. The apathy factor item (ie, It does not matter if I do it or not) indicating students' actions are without consequences, comes closest to considering the external world of self (ie, justification based on perceived perceptions of others), as it likely points to the students' perception of bene fi ts of (in) action. Based on the above statement can be seen that without information seeking, all the factors just justification of a behavior, where behavior that becomes an internal factor when we associate with the characteristics of Digital Natives has several relationships. Not only information seeking, information literacy also affects academic procrastination. This is supported by the results of research conducted by Hariyati and Tarma (2017) proving that information literacy, emotional regulation, and self-directed effect on academic procrastination.

There are factors influencing student academic procrastination. Ferrari (1995) says that the factors that affect academic procrastination are categorized into Internal and external factors. Internal factors contained of: individual's physical condition (physical condition and individual health condition); and individual psychological condition (eg self-regulation \& motivation). In the other hands, external factors which related to parenting style and environmental conditions. Scraw, Olafson, \& Wadkins (2007) states that factors causing procrastination are grouped into 3 categories: a) Characteristics of self / individual (interest and ability to manage time); b) Characteristics of teachers / lecturers (related clarity in giving instructions), and; c) Task characteristics (level of knowledge and difficulty level) 
These condition indicate that the characteristics of Z-generation students who use the internet as their source of information in completing tasks, it makes them choose to postpone the task given by doing more fun activities. That is, the characteristics of the task given are considered less challenging for them, because everything is available on the internet. Morever, Patrzek, Grunschel, \& Fries (2012), stated several leading factors for academic procrastination and categorised as follow:

1. Internal Factors

a. personality-related (Negative selfimage, avoidance, perfectionist)

b. competency-related (deficient learningmanagement, deficient self-regulation, deficient decision-making, deficient study skills, lack of knowledge)

c. affective (anxiety, shame, frustration, feeling pressured, feeling overmheimed)

d. cognitive (worries, loss of perspectives)

e. learning history (learned behavior, negative learning experience)

f. mental and physical state (impaiment, illness)

g. perceived task characteristic (aversiveness, interestingness, difficulty, amount, importance, quality of alternative task)

\section{External Factors}

a. private lives (lack of social network, continuous stress factors, critical live events)

b. university-related (lecture's qualities, condition at university)

This poses challenges for educators facing Zgeneration students who are in particular now entering higher education, and will be a new challenge for human resource management if in future $\mathrm{Z}$ generation has entered the workforce. Furthermore, Fauziah (2015) stated there are 3 factors that cause academic procrastination those are: a) Physical, including fatigue; b) Psychic, including clarity of task instructions, feeling lazy, the use of time, interest, mood; c) Environment, including the level of difficulty of the task, support facilities, reference limitations,collection period, friend support, off-campus activity and task build-up.

\section{E. Characteristics of Faculty of Teacher Training and Education UNS Student}

The development of information and technology must also be balanced with information literacy and digital literacy. Based on the observations of the researcher, Faculty of Teacher Training and Education UNS students generally have characteristics such as: (1) students are in campus environment equipped with wifi facility to support easiness in accessing internet; (2) most of the students already have smartphones and laptops / notebooks to support the learning process, especially in doing the task; (3) the learning resources available in the library are already using the digital library system to facilitate students in accessing e-resources consisting of various types such as e-books, ejournals, etc.

With all of those facilities, students are enjoying their daily academics activities as they enjoy their smartphone with internet access as unconditional part of their body. This condition lead many of them in serious academic procrastination which unreasonably more to the negative impact rather than positive.

\section{F. Correlation of Academic Procrastination on Digital Natives High Student}

With the information literacy, students are expected to be able to access, evaluate and use the information needed effectively. $\mathrm{Z}$ generation is smart, with the ability to process a lot of information quickly (West, 2014). Taylor (Dubnjakovic, 2018) found that students increasingly engage in the process of "backfiling" (adding sources of information shortly before submission deadlines).

Students as part of the academics who certainly need more information in completing the tasks of lectures and for the development of scientific, not impossible to find the information needs it (Nature, 2013: 93). Pattah (2014: 118) also stated that in doing the assigned lecture, some students even complain that they do not have the information source to complete their college tasks, even if they access from the internet by quoting some sources that are not suitable for reference because they can not be held responsible for legality the text. Junco and Cotten (2011) argue that the Internet is used to collect information relating to the task, as a medium of communication with classmates to discuss the task being done. Behind these benefits, the internet also provides negative consequences, namely cyberslacking. According to Geokçearslan (Putri \& Sokang, 2017: 9) cyberslacking is a behavior of using the internet in a learning environment for personal gain unrelated to classroom assignments. Blanchard \& Henle stated that one of the important features of cyberslacking is that the motive of cyberslacking is to avoid tasks and explore the more favored things on the internet (Putri \& Sokang, 2017: 9). Research results Tindell and Bohlander (2012) states that students use their smartphones to access the internet when they are in class. Information obtained by students when accessing the internet in the classroom, whether information that can be directly applied in the classroom or other information, can help students in doing their work. The implications of investigating procrastination as an independent media (Meier, Reinecke, \& Meltzer, 2016: 65). 
Pattah (2014: 118) argues that "there are still many students who only use internet facilities just for social networking, games, etc. .. Even if they use some search engines such as Google, Yahoo, etc. in searching for information sources, most of the students have not been assess which ones have value of information and which are just rubbish ". Pattah also argues that the presence of the Internet with various electronic and digital sources makes people increasingly aware of the importance of information skills, to be able to help find the information in accordance with the needs and empower the information obtained.

Following table below is a summary of mentioned characteristic at the previous section.

TABLE 2: SUMMARY OF CHARACTERISTIC OF DIGITAL NATIVE STUDENT AND ACADEMIC PROCRASTINATION FACTORS

\begin{tabular}{|c|c|}
\hline $\begin{array}{c}\text { Characteristics of Digital } \\
\text { Natives } \\
\text { High Student }\end{array}$ & Academic Procrastination Factors \\
\hline $\begin{array}{l}\text { Mastery of information } \\
\text { and technology }\end{array}$ & $\begin{array}{l}\text { Competence (deficient study skills, } \\
\text { lack of knowledge) }\end{array}$ \\
\hline $\begin{array}{l}\text { Not aware of concept of } \\
\text { struggling }\end{array}$ & $\begin{array}{l}\text { Learning history (learned behavior, } \\
\text { negative learning experience) }\end{array}$ \\
\hline Brave & $\begin{array}{l}\text { Characteristics of } \quad \text { task } \\
\text { (interestingness, difficulty, amount, } \\
\text { importance) }\end{array}$ \\
\hline $\begin{array}{l}\text { More impatient and more } \\
\text { agile than predecessors }\end{array}$ & $\begin{array}{l}\text { Environtment (support facilities, } \\
\text { reference limitations, collection } \\
\text { period) }\end{array}$ \\
\hline $\begin{array}{l}\text { Look for new challenges } \\
\text { and impuls continuously } \\
\text { Sosial media savvy } \\
\text { Multitaskers }\end{array}$ & \\
\hline $\begin{array}{l}\text { Concerned about the } \\
\text { environment }\end{array}$ & \\
\hline $\begin{array}{l}\text { Influenced by their } \\
\text { friends about product and } \\
\text { brands }\end{array}$ & \\
\hline $\begin{array}{l}\text { Smart, with the ability to } \\
\text { process a lot of } \\
\text { information quickly }\end{array}$ & \\
\hline
\end{tabular}

\section{CONCLUSION}

With the information literacy, students are expected to be able to access, evaluate and use the information needed effectively. $\mathrm{Z}$ generation is smart, with the ability to process a lot of information quickly (West, 2014), and Taylor (2012) found that students increasingly engage in the process of "backfiling" (adding sources of information shortly before submission deadlines). Nevertheless, academic procrastinations still put important role to set and shape higher degree students' motivations and abilities to finish and accomplish their daily task. In the other hands, the recent condition on generation $\mathrm{Z}$ has given special consideration to lectures and academic managers to accommodate, create and develop tasks based on this situation. Lectures need to be more creative to set their standard and to avoid the academic procrastination. Finally, lectures nowadays are in a competitive race to their students in term of using any internet-based information.

\section{ACKNOWLEDGMENTS}

This finding was only focused only to Departement of Accounting Education, Faculty of Education and Teacher Training, Universitas Sebelas Maret. Expanding the numbers of respondents, suggested will enhanche the final result. It is condiderable as future direction.

\section{REFERENCES}

[1] Aziz, A. \& Rahardjo, P. (2013). Faktor-faktor Prokrastinasi Akademik Pada Mahasiswa Tingkat Akhir yang Menyusun Skripsi di Universitas Muhammadiyah Purwokerto Tahun Akademik 2011/2012. PSYCHO IDEA, 1, 61-68.

[2] Baskoro, D. G., \& Jonatan, E. (2015). Kompetensi Literasi Informasi Pustakawan Universitas Swasta di Lingkungan Kopertis Wilayah III. Jurnal Pustakawan Online Tahun 2015, 1-13. http://pustakawan.perpusnas.go.id/jurnal/201 5/index.html

[3] Bencsik, A., Csikos, G., \& Juhaz, T. (2016). Y and Z Generations at Workplaces. Journal of Competitiveness, 8(3) 90-106.

[4] Bencsik, A., \& Machova, R. (2016). Knowledge haring Problem from the Viewpoint of Integration Management. In ICMLG2016-4th International Conference on Management, Leadership and Governance. Academic Conferences and publishing limited.

[5] Dubnjakovic. (2018). Neutralization Role in College Student's Information Seeking Procrastination. New Review of Academic Librarianship, 1-17. https://doi.org/10.1080/13614533.2018.1431294

[6] Eberhardt, D. (2017). Generation Z Goes to College. Journal of College and Character, 18(3) 221-223.

[7] Fauziah, H.H. (2015). Faktor-faktor yang Mempengaruhi Prokrastinasi Akademik Pada Mahasiswa Fakultas Psikologi UIN Sunan Gunung Djati Bandung. Psympatic, Jurnal Ilmiah Psikologi, 2(2) 123-132.

[8] Ghufron, M.N \& Risnawita, R.S.(2012). TeoriTeori Psikologi. Yogyakarta: Ar-Ruzz Media.

[9] Grassian, E. (2017). Teaching and Learning Alternatives: A Global Overview. Reference \& User Services Quarterly, 56(4) 232-239.

[10] Hariyati, N. \& Tarma. (2017). Determinant Factor of Student Procrastination Behavior of Technical and Vocational Teacher Education. Advance in Social Science, Education and Humanities Research (ASSEHR), 66, 305-309.

[11] Junco, \& Cotten. (2012). No A 4 U: The Relationship between multitasking and academic performance. Computer \& Education, 59 (2), 505-514.

[12] Kathleen A. J. M., \& Eric S. M. (2017). Understanding Generation Z Students to Promote a Contemporary Learning Environment. Journal on Empowering Teaching Excellence: Vol. 1 : Iss. 1, Article 9.

[13] Meier, A., Reinecke, L., \& Meltzer, C.E. (2016). Facebrocrastination? Predictors of Using Facebook for Procrastination and its effect on students' well-being. Computerin Human Behavior (64) 65-76.

[14] Nurjanah, Rusmana, dan Yanto. (2017). Hubungan Literasi Digital dengan Kualitas 
Penggunaan E-Resources. Lentera Pustaka, 3(2) 117-140.

http://ejournal.undip.ac.id/index.php/lpustaka

[15] Pattah, S.H. (2014). Literasi Informasi: peningkatan kompetensi informasi dalam proses pembelajaran. Jurnal Ilmu Perpustakaan \& Kearsipan Khizanah Al-Hikmah, 2(2) 117-128.

[16] Patrzek, J., Grunschel, C., \& Fries, S. (2012). Academic Procrastination: The Perspective of University Counsellors. International Journal Adv. Counselling, 34, 185-201.

[17] Putra, Y., S. (2016). Theoritical review: Teori Perbedaan Generasi. Among Makarti, 9(18) 123132

[18] Putri, Y.V.S., \& Sokang, Y.A. (2017). Gambaran Cyberslacking Pada Mahasiswa. Prosiding Konferensi Nasional Peneliti Muda Psikologi Indonesia, 2(1), 9-17.

[19] Scraw, G., Olafson, L., \& Wadkins, T. (2007). Doing the Things We Do: A Grounded Theory of Academic Procrastinatiom. Journal of Educational Psycology, 99(1) 12-25.

[20] Seemiller, C., \& Grace, M. (2016). Generation Z Goes to College. New York, NY: Jossey-Bass.
[21] Sorgo, A., Bartol, T., Dolnicar, D., \& Podgornik, B.B. (2016). Attributes of digital natives as predictors of information literacy in higher education. British Journal of Educational Technology, 1-19.

[22] Sukaesih, S. and Rohman, A.S. (2013). Literasi Informasi Pustakawan: Studi Kasus Di Universitas Padjadjaran. Jurnal Kajian Informasi dan Perpustakaan, 1(1) 61-72.

[23] Surachman, A. (2012). Pengembangan EResources: Salah Satu Upaya Membangun Perpustakaan Digital. Universitas Gajah Mada: Yogyakarta.

[24] Tindell, D. R., \& Bohlander, R. W. (2012). The use and abuse of cell phones and text messaging in the classroom: A survey of college students. College Teaching, 60(1), 1-9.

[25] Yudistira. (2017). Literasi Informasi Pustakawan di Perpustakaan Fakultas Teknik UGM Menggunakan Pengembangan Model The Big6. Berkala Ilmu dan Informasi, 13(1) 97-106 http://10.22146/bip.26069

[26] West, M. (2014). What Manufacturers Need to Know About Generation Z. Manufacturing Engineering, 153(01) $168-168$. 